\title{
Bee Venom Inhibits Angiogenesis by Decreasing HIF-1a Expression in HCT116 Cells
}

\author{
Jae-Moon Shin ${ }^{1,2}$, Yun-Jeong Jeong ${ }^{1,2}$, Kwan-Kyu Park ${ }^{1,2}$, Jung-Yoon Choe ${ }^{1,2}$, Sang-Mi Han ${ }^{3}$,
} Kwang-Gill Lee ${ }^{3}$, Joo-Hong Yeo ${ }^{3}$, II-Kyung Chung ${ }^{4}$ and Young-Chae Chang ${ }^{1,2}{ }_{*}$

${ }^{1}$ Research Institute of Biomedical Engineering and ${ }^{2}$ Department of Medicine, Catholic University of Daegu School of Medicine, Daegu 705-718, Korea

${ }^{3}$ Department of Agricultural Biology, National Institute of Agricultural Science and Technology, Suwon, Kyunggi-Do 441-100, Korea ${ }^{4}$ Department of Biotechnology, Catholic University of Daegu, Gyeongsan 712-702, Korea

Received October 10, 2011 /Revised December 30, 2011 /Accepted January 9, 2012

\begin{abstract}
Bee venom (BV) has been used in medicine to treat a variety of diseases including arthritis, rheumatism, and various cancers. Recent reports indicate that BV has anti-angiogenic effects, but the precise molecular mechanism underlying the effects of BV against colorectal cancer remains to be elucidated. We examined the effects of BV and its major components (melittin and apamin) on tumor angiogenesis and found that BV significantly decreased protein levels of hypoxia-inducible factor-1a (HIF-1 a), an important factor involved in angiogenesis and tumor progression, in human colorectal carcinoma HCT116 cells. BV also suppressed the transcription of HIF-1a under hypoxia, leading to a decrease in the expression of vascular endothelial growth factor (VEGF), a major target gene of HIF-1a. We also found that these effects were mainly elicited by apamin, but not melittin. BV specifically inhibited the phosphorylation of ERK1/2 without changing the total levels of this protein, but had no effect on kinases of p38/JNK and AKT. Our results suggest that BV may inhibit human colorectal cancer progression and angiogenesis by inhibiting HIF-1a and VEGF expression, thereby providing a novel potential mechanism for the anticancer action of BV.
\end{abstract}

Key words : Angiogenesis, HIF-1a, VEGF, bee venom

\section{서 론}

신생혈관생성(angiogenesis)은 정상세포의 상처나 암세포 의 성장 과정에서 영양분과 산소의 공급을 위한 필수적인 과 정 중 하나이다[10]. 암세포의 신생혈관생성 정도는 암의 진행 과[5], 전이에 중요한 역할을 하며, 암세포에서 분비되는 혈관 생성 촉진인자 발현의 증가로 조절된다. 현재까지 20 여 가지 이상의 혈관생성 촉진인자가 알려져 있으며, 그 중 vascular endothelial growth factor (VEGF)는 암세포에서 가장 많이 분비되는 인자로써 암세포의 신생혈관생성에 중요한 역할을 한다[7,18]. VEGF는 저산소(hypoxia), growth factor, 활성산 소 및 스트레스와 같은 여러 자극으로 인해 발현이 증가되며 [2] hypoxia-inducible factor-1 (HIF-1)에 의해 전사수준이 조 절된다 $[8,27,28]$.

HIF-1은 VEGF를 포함한 많은 유전자를 조절하는 전사인자 로써, $\mathrm{VEGF}$ 의 promoter의 hypoxia response element (HRE) 에 결합하여 VEGF 유전자 발현을 활성화시킨다[36]. HIF-1는 세포내의 $\mathrm{O}_{2}$ 수준감소에 의해 발현되는 HIF-1a와 세포의 구성 성분으로 발현되는 HIF-1 $\beta$ 로 이루어져 heterodimer를 형성하

*Corresponding author

Tel : +82-53-650-4848, Fax : +82-53-650-4849

E-mail : ycchang@cu.ac.kr
고 있으며 HIF- $1 a$ 의 안정화에 의해 발현이 조절된다 $[24,37]$. HIF-1a는 세포의 산소 농도가 정상 상태일 경우 산소가 요구 되는 효소적 과정을 통하여 Pro-564와 Pro-402가 수산화됨으 로 인해 von hippel-lindau (VHL)에 빠르게 결합하여[12] ubiquitination system으로 분해된다[14]. 그러나 저산소 또는 이온으로 수산화를 억제시킨 상태에서는 분해되지 않고 핵으 로 전위하여 전사조절인자로써의 역할을 한다[20]. 또한 HIF-1 $a$ 는 산소에 비의존적으로 여러 가지 성장인자, cytokines 또는 분자 간 신호전달에 의해 조절될 수 있다. 이러한 분자적 자극 은 phosphatidylinositol 3-kinase (PI3K)/AKT pathway와 mitogen-activated protein kinase (MAPK) pathway을 활성 시킴으로써 HIF-1a 단백질 발현을 조절한다[6].

봉독은 벌꿀의 독낭에 들어있는 40 여 가지 유효성분으로 구성된 물질로써 염증 및 알레르기 등을 유발하는 것으로 알 려져 왔다. 예로부터 민간 요법에 자주 사용되어 왔으며, 현재 임상적 실험을 통해 진통, 소염의 효능이 탁월하다는 것이 확 인되었다. 봉독은 크게 peptide components, non-peptide components, 효소 성분으로 구성되어 있으며, 봉독의 $50 \%$ 이 상을 차지하고 있는 peptide components에 아파민, 멜리틴, mast cell degranulating (MCD) 등의 주요 생리활성 성분이 있다. 현재 봉독은 항염증과 항동맥경화 뿐만 아니라 항암효 과에 대한 연구가 많이 진행되고 있다[3,4]. 봉독의 항암효과로 
간암 세포와 피부암 세포인 흑색종 세포의 증식을 억제하고, 백혈병 세포에서 세포자살 효소인 bcl-2, caspase-3를 활성화 시켜 세포자살을 유도하며[15,32], 신장암 세포에서 ERK/ AKT 신호전달 조절을 통한 증식을 억제한다고 보고되었다 $[19,23]$. 또한, 최근 암세포의 신생혈관생성 억제에 관한 연구 가 보고되었으나[13,34], 그에 관한 신호전달 기전 연구는 아직 충분하지 못한 실정이다.

따라서, 본 연구는 봉독의 신생혈관생성 억제에 관한 신호 전달 기전을 조사하기 위하여, 인간대장암 세포주인 HCT116 세포에 cobalt chloride $\left(\mathrm{CoCl}_{2}\right)$ 로 저산소와 유사한 상태를 유 도하여 $[1,29,30]$, 봉독이 신생혈관생성에 주요한 인자인 HIF-1 $a$ 와 VEGF 발현에 미치는 영향과 조절기전을 확인하였다.

\section{재료 및 방법}

\section{세포배양과 봉독}

실험에 사용한 HCT116세포(human colorectal carcinoma cell)는 American type culture collection (Rockville, MD USA)에서 분양 받아 사용하였으며, $1 \%$ antibiotics (GIBCOBRL, Invitrogen Co., Grand Island, USA), 10\% fetal bovine serum (FBS) (GIBCO-BRL)가 포함된 dulbecco's modified eagle's medium (DMEM, Carlsbad, CA, USA)배지를 사용하 여 $37^{\circ} \mathrm{C}, 5 \% \mathrm{CO}_{2}$ 조건에서 배양하였다. 봉독은 한국농촌진흥 청 (국립농업과학원)에서 지원 받아 멸균된 3차 증류수에 희석 하여 사용하였다.

\section{$\mathrm{MTT}$ 측정}

봉독 농도에 따른 세포생존율을 측정하기 위해 세포 $\left(1 \times 10^{4}\right.$ cells/well)를 96 well plate에 분주하여 24 시간 안정화시킨 후, 봉독을 농도별로 처리하여 24 시간 배양하였다. 배양한 다음 3[4,5-dimethylthiazol 2 -yl]-2.5-diphenyltetra-zolium bromide (MTT) (Roche Applied Science, Indianapolis, IN, USA) 시약 을 처리하여 4 시간 반응시켰다. 반응 후 상등액을 제거하고 dimethylsul foxide (DMSO, Sigma Chemical Co. St. Louis, $\mathrm{MO}, \mathrm{USA}$ )을 처리하여 생성된 formazin을 용해한 다음 ELISA reader (Molecular Devices, Sunnyvale, CA, USA)로 $540 \mathrm{~nm}$ 에서 흡광도를 측정하였다.

\section{Western blot 분석}

세포 내 존재하는 단백질을 분리하기 위하여 total lysis buffer (50 mM Tris, $150 \mathrm{mM} \mathrm{NaCl}, 5 \mathrm{mM}$ EDTA, $1 \mathrm{mM}$ DTT, $0.5 \%$ nonidet $\mathrm{P}-40,100 \mathrm{mM}$ phenylmethylsulfonyl fluoride, $20 \mathrm{mM}$ aprotinin, $20 \mathrm{mM}$ leupeptin, $\mathrm{PH}$ 8.0)를 넣고 $4^{\circ} \mathrm{C}$ 에서 30 분 간 용해한 후, 원심분리(12,000 rpm, 10 분)하여 상등액 을 취하였다. 또한 세포질/핵 내 단백질을 분리하기 위해 세포
에 buffer A [10 mM Hepes (pH 7.9), $1.5 \mathrm{mM} \mathrm{MgCl}, 10 \mathrm{mM}$ $\mathrm{KCl}, 0.5 \mathrm{mM}$ DTT, $300 \mathrm{mM}$ Saccharose, 0.1\% NP-10, $0.5 \mathrm{mM}$ phenylmethylsulfonyl fluoride]를 가하여 $44^{\circ} \mathrm{C}$ 에서 5 분 용해 시킨 후 원심분리(1,000 rpm, 1 분)로 pellet (핵 단백질)을 분리 하였다. 분리된 pellet을 buffer B [20 mM Hepes (pH 7.9), $20 \%$ glycerol, $100 \mathrm{mM} \mathrm{KCl}, 100 \mathrm{mM} \mathrm{NaCl}, 0.2 \mathrm{mM}$ EDTA, $0.5 \mathrm{mM}$ DTT, $0.5 \mathrm{mM}$ phenylmethylsulfonyl fluoride]로 $4^{\circ} \mathrm{C}$ 15 분 용해 하여 원심분리( $10,000 \mathrm{rpm}, 5$ 분)로 핵 내 단백질을 분리하였다. 위와 같은 방법으로 추출한 단백질을 SDSpolyacrylamide gel 전기영동 후 단백질을 nitrocellulose membrane (Schleicher \& schuell, Keene, NH, USA)로 전기이 동시켰다. 특이 단백질을 탐색하기 위하여 $5 \%$ skim milk가 함유된 TBS-T로 1 시간 반응시켜 비특이적인 단백질을 blocking 후, 특정 단백질에 대한 항체 HIF-1a, HIF-1ß, ERK1/2, AKT, p38, JNK, $\beta$-actin (Snata Cruz Biotechnology Inc., CA, USA)을 $2.5 \%$ skim milk가 함유된 TBS-T $(10 \mathrm{mM}$ Tris, $150 \mathrm{mM} \mathrm{NaCl}$ and $0.1 \%$ Tween-20)에 1:1,000으로 희석 하여 반응시켰다. 반응된 membrane에 특정항체 대한 이차항 체를 처리 한 후 enhanced chemil luminoesence (ECL, Amersham Life Science Co., Arlington Heights, IL, USA)를 사용하여 X-ray film에 감광시켜 특정 단백질의 발현량을 분 석하였다.

\section{RT-PCR}

세포의 RNA를 추출하기 위해 TRlzol (Invitrogen Co., Grand Island, NY, USA)를 사용하였으며, OD260과 OD280 에서 흡광도를 측정하여 동량의 total RNA와 oligo (dT)을 RT premix kit (Bioneer, korea)을 사용하여 cDNA를 합성하였다. 합성된 cDNA를 특정 primer (VEGF; forward 5 '-ctgagc ctctctaccccagg- $3^{\prime}$, reverse $3^{\prime}$-gagcaggaagaggatgaggg- $\left.5^{\prime}\right)(\beta-$ actin; forward $5^{\prime}$-agggtgtgatgggtatggg- $3^{\prime}$, reverse $3^{\prime}$-caggatc ttcatgaggtagtc- $5^{\prime}$ ) 유전자 중심으로 PCR방법으로 증폭하여 cDNA을 $1.5 \%$ agarose gel로 전기영동하고 ethidium bromide $(\mathrm{EtBr})$ 로 염색한 후 UV 하에서 확인하였다.

\section{HRE promoter 활성 분석}

pGL3-HRE-luciferase 사용하여 실험을 수행하였다. 6-well plate에 세포 $\left(1 \times 10^{4}\right.$ cells/well) 배양한 후, PGL3-HREluciferase와 pCMA- $\beta$-galactosidas을 DNA transfection reagent (TranslT-LT1 transfection reagent, Mirus, Madison, WI, USA)을 사용하여 12 시간 cotransfection 하였다. 배지를 교체하고 명시된 시료를 처리하여 12 시간 배양 후 lucferase와 $\beta$-galactosidase의 효소 활성을 commercial kits (Promega, Madison, $\mathrm{WI})$ 을 사용하여 측정하였다. $\beta$-galactosidase는 대 조군으로 사용하였다. 


\section{통계처리 분석}

실험 결과의 통계적 처리는 student's $t$ test 및 analysis of variance (ANOVA)로 하였으며, P 값 < 0.05 을 유의한 차이의 한계로 하였고, 실험결과의 표현은 means \pm S.E로 하였다.

\section{결 과}

\section{봉독의 $\mathrm{HIF}-1 \mathrm{a}$ 발현 억제 효과}

봉독이 HCT116 사람 대장암 세포의 생존율에 미치는 영향 을 알아보기 위하여 MTT 분석을 수행하였다. 봉독 0.5 4 $\mathrm{\mu g} /$ $\mathrm{ml}$ 의 농도에서 HCT116세포 생존율을 확인한 결과, 봉독 2 $\mu \mathrm{g} / \mathrm{ml}$ 이하의 농도에는 세포 생존율에 영향을 미치지 않았으 나, $4 \mu \mathrm{g} / \mathrm{ml}$ 에서 세포 생존율이 약 $80 \%$ 감소하였다(Fig. 1A). 이 결과를 기준으로 하여 이후의 실험은 시료가 세포에 독성 을 끼치지 않은 $2 \mu \mathrm{g} / \mathrm{ml}$ 이하의 농도에서 실험을 수행하였다. 봉독이 신생혈관생성에 주요한 역할을 하는 HIF-1a에 미치는

A

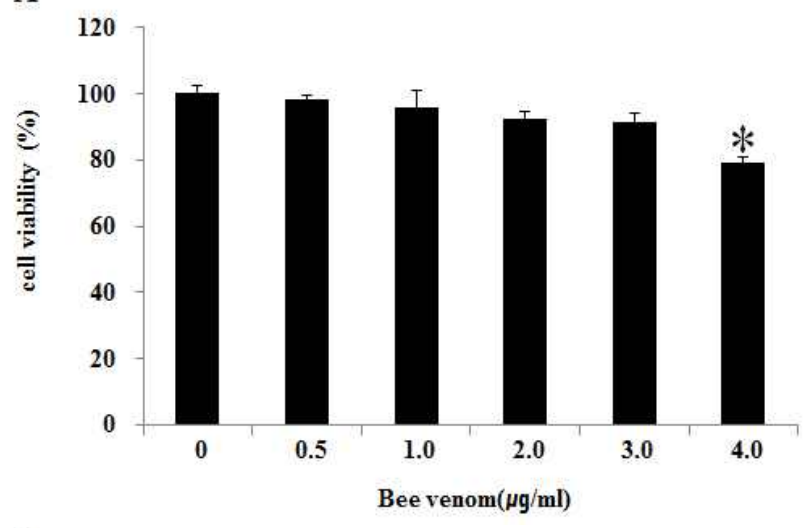

B

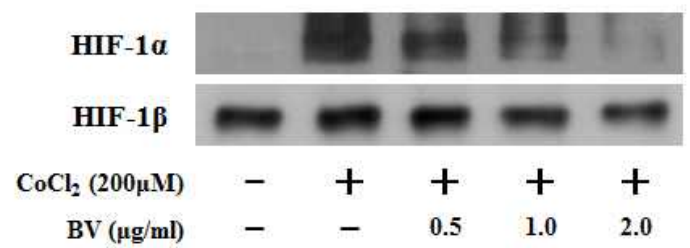

Fig. 1. Effect of bee venom on $\mathrm{CoCl}_{2}$-induced HIF-1a expression in HCT116 cells. (A) Dose-dependent effect of bee venom on the viability of HCT116 cells. Cells were treated with the indicated concentrations of bee venom for $24 \mathrm{hr}$. Viability was determined by MTT assay. Values represent the means \pm SD of triplicate assays. ${ }^{*}, p<0.05$ as compared to untreated control. Results were analyzed using one-way ANOVA. (B) HIF-1a expression in the presence of bee venom in HCT116 cells. Cells were pretreated with the indicated concentrations of bee venom for $30 \mathrm{~min}$, and then stimulated by $\mathrm{CoCl}_{2}(200$ $\mathrm{mM}$ ) treatment for $6 \mathrm{hr}$. Nuclear extracts were subjected to Western blot using antibodies against HIF-1a and HIF-13.
영향을 확인하기 위해 western blot 분석을 수행하여 HIF-1a 단백질 발현을 확인하였다(Fig. 1B). HCT116세포에 저산소와 유사한 상태를 만들기 위해 $\mathrm{CoCl}_{2}$ 처리한 결과 $\mathrm{HIF}-1 \mathrm{a}$ 단백질 발현이 증가하였으며, 봉독을 같이 처리하였을 때 농도-의존 적으로 감소하였다. 반면 $\mathrm{CoCl}_{2}$ 와 봉독은 $\mathrm{HIF}-1 \beta$ 의 발현에는 영향을 끼치지 않았다(Fig. 2B). 위와 같은 결과로 세포독성이 없는 봉독 $2 \mu \mathrm{g} / \mathrm{ml}$ 이하의 농도에서 HIF-1a 발현이 감소되었 기 때문에 봉독의 HIF-1a 발현 감소효과가 세포독성에 기인한 것이 아님을 확인하였다.

\section{봉독의 VEGF 전사 억제 효과}

$\mathrm{HIF}-1$ 에 의해 조절되는 VEGF의 전사 활성에 봉독이 영향 을 끼치는지 확인하기 위해 VEGF mRNA 수준을 조사하였다 (Fig. 2). $\mathrm{HCT116세포에} \mathrm{CoCl}_{2}$ 처리로 유도된 VEGF mRNA 수준이 봉독 $2 \mu \mathrm{g} / \mathrm{ml}$ 처리 시 감소하였다(Fig. 2A). 또한 HIF-1 유전자가 결합하는 promoter 영역인 HRE promoter
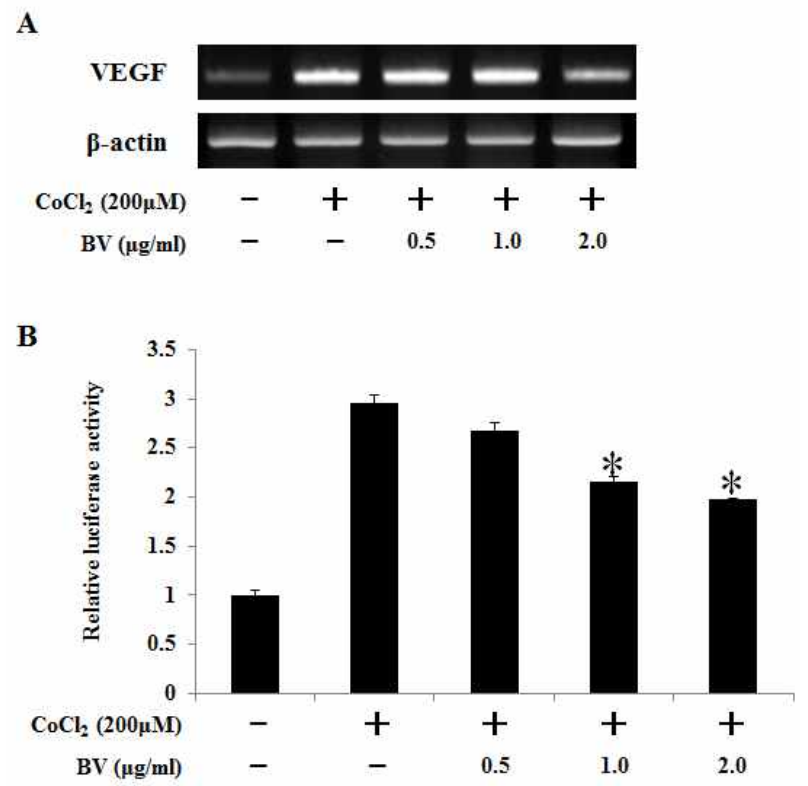

Fig. 2. Effect of bee venom on $\mathrm{CoCl}_{2}$-induced VEGF mRNA expression and HRE-mediated reporter gene in HCT116 cells. (A) RT-PCR analysis of VEGF mRNA was carried out using total RNA prepared from HCT116 cells incubated with $200 \mu \mathrm{M} \mathrm{CoCl}_{2}$ treatments for $12 \mathrm{hr}$ in the presence or absence of the indicated concentrations of bee venom. (B) HCT116 cells were transiently co-transfected with a reporter gene, pGL3-HRE -Luciferase, and pRL-CMV as a reference. Following incubation for $24 \mathrm{hr}$, the cells were incubated with $\mathrm{CoCl}_{2}$ treatment in the presence or absence of indicated concentration of bee venom. Data represents the means \pm SD of three independent experiments. ${ }^{*}, p<0.05$ as compared to $\mathrm{CoCl} 2$-treated control. Results were analyzed using one-way ANOVA. 
A

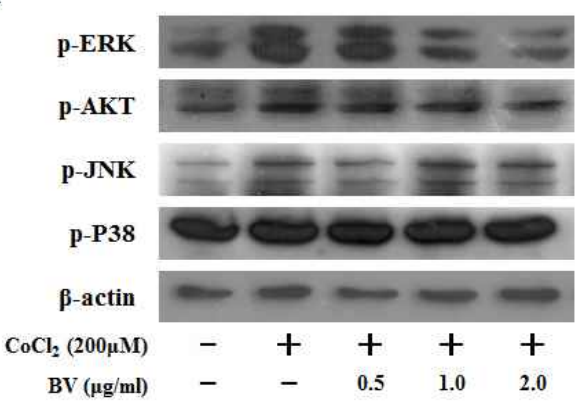

B

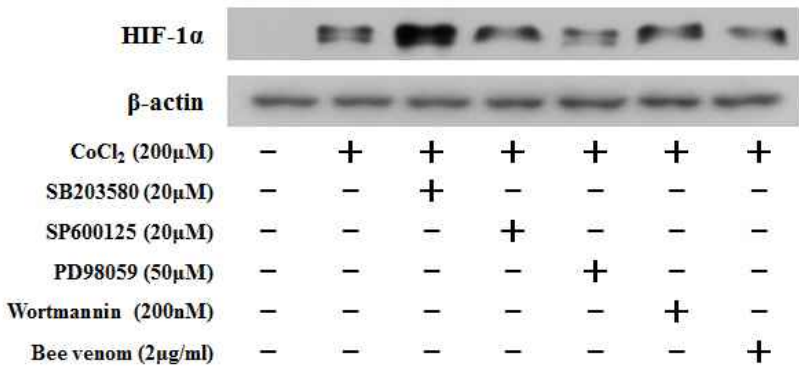

Fig. 3. Effect of bee venom on $\mathrm{CoCl}_{2}$-induced signaling leading to the expression of HIF-1a in HCT116 cells. (A) HCT116 cells were pretreated with the indicated concentrations of bee venom for $1 \mathrm{hr}$, followed by incubation with 200 $\mu \mathrm{M} \mathrm{CoCl} 2$ for $15 \mathrm{~min}$. The phosphorylated levels of AKT, JNK, P38 and ERK were determined by Western blot analysis. (B) HCT116 cells were pretreated with Bee venom $(2 \mu \mathrm{g} / \mathrm{ml})$, SB203580 $(20 \mu \mathrm{M})$, SP600125 $(20 \mu \mathrm{M})$, PD98059 $(50 \mu \mathrm{M})$, Wortmannin $(200 \mathrm{nM})$ for $30 \mathrm{hr}$, and then stimulated by $\mathrm{CoCl}_{2}$ treatment for $6 \mathrm{hr}$. Nuclear extracts were subjected to Western blot using antibodies against HIF-1a or $\beta$-actin.

활성을 측정한 결과 $\mathrm{HCT} 116$ 세포에 $\mathrm{CoCl}_{2}$ 처리로 유도된 $\mathrm{HRE}$ promoter 활성이 봉독 농도-의존적으로 감소하는 것을 확인하였다(Fig. 2B). 따라서 봉독이 HIF-1a 발현과 HRE promoter 활성의 억제를 통하여 VEGF 전사활성을 감소시키 는 것을 알 수 있다.

\section{봉독이 MAP kinase에 미치는 영향}

위 실험으로 봉독이 HIF-1a의 발현을 효과적으로 감소시키 는 것을 확인하였다. 따라서, 봉독이 어떠한 신호전달을 조절 하여 HIF-1a의 발현을 억제하는지 확인하기 위하여 HIF-1a 단백질의 상위 조절자로 알려진 $\mathrm{AKT}$ 와 MAP kinase의 활성 을 조사하였다[7]. HCT116세포에 $\mathrm{CoCl}_{2}$ 처리한 결과 AKT, $\mathrm{JNK}, \mathrm{ERK} 1 / 2$ 의 인산화가 증가되었으며, 봉독을 같이 처리하 였을 때 ERK1/2의 인산화가 봉독 농도-의존적으로 감소하였 다. 그러나, AKT, JNK, p38은 봉독에 영향을 받지 않았다(Fig. $3 A)$.
이와 같은 결과, 봉독이 $\mathrm{ERK} 1 / 2$ 의 인산화를 효과적으로 조절함을 알 수 있었으므로 봉독의 HIF-1a의 발현 저해 효과 가 $\mathrm{ERK} 1 / 2$ 인산화 억제에 의한 것인지 확인하기 위하여 $\mathrm{ERK} 1 / 2, \mathrm{AKT}, \mathrm{JNK}, \mathrm{p} 38$ 단백질 저해제와 봉독을 각각 처리하 여 HIF-1a 단백질 발현을 조사하였다. HCT116세포에 $\mathrm{CoCl}_{2}$ 처리로 유도된 HIF-1a 발현이 PD98059 (ERK1/2 저해제)와 봉독처리에 의해 HIF-1a 발현이 감소하였다. 그러나, SP600125 (JNK 저해제), Wortmannin (AKT 저해제) 처리에는 HIF- $1 a$ 의 발현이 변화가 없었다(Fig. 3B). 이 결과 HIF-1a 단백 질 발현 감소는 $\mathrm{ERK} 1 / 2$ 의 인산화 조절에 의한 것임을 확인 할 수 있었다.

\section{봉독의 주요 구성 성분이 신생혈관생성에 미치는 영향}

앞의 실험결과를 통하여 봉독이 HIF-1a를 억제함으로 인해 신생혈관생성에 주요한 인자인 VEGF를 억제하는 것을 확인 하였다. 따라서, 봉독의 생리활성물질 중 어떠한 물질이 신생 혈관생성 억제 효과가 있는지 확인하기 위하여, 봉독의 대표 적인 생리활성 물질로 알려진 멜리틴과 아파민을 사용하여 HIF-1a 단백질 발현과 VEGF mRNA 수준을 조사하였다. $\mathrm{HCT} 116$ 세포에 $\mathrm{CoCl}_{2}$ 처리로 유도된 HIF-1a 발현이 아파민 농도-의존적으로 감소하였으며, VEGF mRNA 수준 또한 아파 민 $2 \mu \mathrm{g} / \mathrm{ml}$ 에서 감소하였다(Fig. $4 \mathrm{~A}$ ). 반면 멜리틴 농도 2 $\mu \mathrm{g} / \mathrm{ml}$ 에서 HIF-1a 발현은 감소하였으나, VEGF mRNA 수준 은 감소시키지 않았다(Fig. $4 \mathrm{~B})$. 이와 같은 결과로 봉독의 신생 혈관억제 효과가 아파민에 기인하는 것으로 예상 할 수 있었 다.

\section{고 찰}

봉독은 동양에서 민간 요법 중 하나인 벌침이라는 침 요법 으로 염증성 질병인 류마티스 질병에 주로 사용되며, 소염 진 통에 효과적인 것으로 알려진 물질이다. 뿐만 아니라 봉독은 암세포 성장 억제 효과를 가진 것으로 알려져 있으며[25,35], in vivo에서 봉독이 VEGF receptors-2 (VEGFR-2)의 타이로신 인산화를 억제 하여 암세포 신생혈관생성을 억제 한다고 보고 되어 있다[13]. 그러나 봉독의 암세포 신생혈관생성 억제 효과 에 대한 신호 전달 기전 연구는 보고된 바가 없다. 따라서, 본 연구에서 신생혈관생성에 주요한 인자인 HIF-1a와 VEGF 에 대한 봉독의 억제효과와 그의 신호전달기전 조절확인을 통해 암세포의 성장억제제와 암 치료제로 사용될 가능성을 연구하였다.

HIF- $1 a$ 는 세포의 산소 농도가 정상 상태일 경우 Pro-564와 Pro-402가 수산화됨에 따라 VHL에 결합하여 ubiquitination system으로 분해된다. 그러나 cobalt chloride, nickel chloride 처리 시 수산화반응을 억제하여 잔기들이 $\mathrm{VHL}$ 와 결합하 지 못하여 세포내에서 분해되지 않고 존재하게 된다[21]. 
A

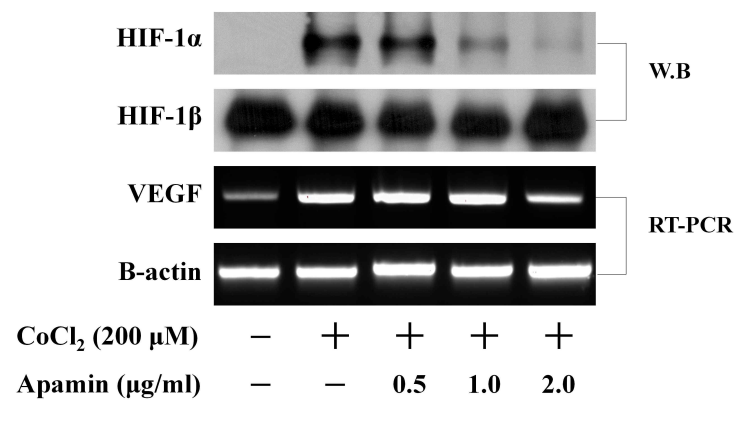

B

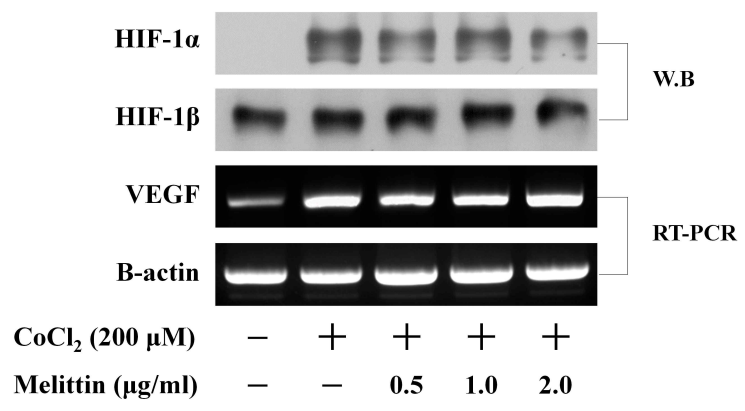

Fig. 4. Effect of components of bee venom, apamin and melittin, on $\mathrm{CoCl}_{2}$-induced HIF-1a and VEGF mRNA expression HCT116 cells. (A)(B) HCT116 cells were pretreated with the indicated concentrations of bee venom its components, apamin and melittin, for $30 \mathrm{~min}$, and then stimulated by $\mathrm{CoCl}_{2}$ treatment for $6 \mathrm{hr}$. Nuclear extracts were subjected to Western blot using antibodies against HIF-1a or HIF-13. RT-PCR analysis of VEGF mRNA was carried out using total RNA prepared from HCT116 cells incubated with $200 \mu \mathrm{M} \mathrm{CoCl}$ treatments for $12 \mathrm{hr}$ in the presence or absence of the indicated concentrations of apamin, melittin.

분해되지 못한 HIF-1a는 세포 핵내로 전이되어 HIF- $1 \beta$ 와 heterodimer를 형성하여 전사인자로 활성화 된다. 특히, HIF-1은 VEGF promoter 영역의 hypoxia response element (HRE)에 결합하여 VEGF 유전자 발현을 활성화시킨다[36]. 따 라서 본 연구에서는 $\mathrm{CoCl}_{2}$ 를 사용하여 $\mathrm{HIF}-1 \mathrm{a}$ 의 발현과 VEGF의 전사를 유도하여 실험을 수행하였다. HCT116세포에 $\mathrm{CoCl}_{2}$ 처리하여 $\mathrm{HIF}-1 \mathrm{a}$ 단백질과 VEGF mRNA를 확인한 결과 모두 증가하였으며, 봉독에 의해 HIF-1a와 VEGF 모두 효과적 으로 감소하였다(Fig. 1B and Fig. 2A). 봉독이 HIF-1a와 VEGF의 억제효과가 있었으므로 HIF-1이 결합하는 HRE promoter 전사활성을 측정하였다. 실험 결과 HCT116세포에 $\mathrm{CoCl}_{2}$ 처리로 유도된 $\mathrm{HRE}$ promoter 활성이 봉독 농도-의존적 으로 감소하였다(Fig. $2 \mathrm{~B})$. 이 결과 봉독은 $\mathrm{CoCl}_{2}$ 에 의해 유도 된 VEGF 전사활성을 HIF-1a 발현과 HRE promoter 활성 감 소를 통하여 신생혈관생성을 억제 한다는 것을 알 수 있었다. 뿐만 아니라 앞서 보고된 봉독의 신생혈관생성 억제 효과는
HIF-1a의 조절에 기인한 것임을 예상 할 수 있다.

많은 연구보고에 따르면 HIF-1a 발현 조절은 여러 성장인 자 자극 또는 미토콘드리아 스트레스 자극에 의해 조절이 되 며 PI3K/AKT/mammalian target of rapamycin (mTOR) 신 호전달 기전 활성과 MAP Kinase 신호전달기전 활성으로 조 절된다고 보고되어 있다[17,31,38]. 세포 성장과 분화에 주요한 역할을 하는 epidermal growth factor (EGF)와 epidermal growth factor receptor (EGFR) 활성이 HIF-1a 발현조절에 관 여 한다고 보고되어 있으며[26], 또한 세포내에서 산소가 정상 상태 또는 저산소 상태에서 세포내의 reactive oxygen species (ROS)가 MAP Kinase 신호전달기전 활성에 관여하여 HIF-1a 발현 조절에 기인한다고 알려져 있다[9,28]. 따라서 $\mathrm{CoCl}_{2}$ 와 봉독에 의한 HIF-1a 발현 조절에 AKT 및 MAP kinase 신호전 달기전이 어떠한 영향을 끼치는지를 Western blot 분석으로 확인하였다(Fig. 3). 그 결과 $\mathrm{CoCl}_{2}$ 는 ERK1/2와 JNK, $\mathrm{AKT}$ 의 인산화를 유도하였으나, p38의 인산화는 변화가 없었다(Fig. 3A). 뿐만 아니라 $\mathrm{CoCl}_{2}$ 에 의해 유도된 $\mathrm{HIF}-1 \mathrm{a}$ 의 발현은 $\mathrm{ERK} 1 / 2$ 저해제인 $\mathrm{PD} 98059$ 에 의해 감소되었으나, $\mathrm{JNK}$ 와 AKT의 저해제인 SP600125와 Wortmannin는 영향을 끼치지 못하였다(Fig. $3 \mathrm{~B})$. 이와 같은 결과는 $\mathrm{CoCl}_{2}$ 에 의한 $\mathrm{HIF}-1 \mathrm{a}$ 의 증가가 ERK $1 / 2$ 의 인산화에 의해 조절되며 $\mathrm{p} 38$, JNK 및 $\mathrm{AKT}$ 는 관여하지 않음을 나타낸다. 따라서 봉독을 처리한 후 $\mathrm{CoCl}_{2}$ 로 유도하여 ERK $1 / 2$ 의 인산화를 확인한 결과 감소하는 것으 로 나타났다(Fig. $3 \mathrm{~A})$. 이와 같은 봉독의 ERK 인산화 억제효과 는 앞서 보고된 봉독의 암세포 성장억제, 세포자살, 전이억제 $[16,23]$ 등의 결과와 동일한 것으로 나타났다. 또한 흥미롭게도 $\mathrm{CoCl}_{2}$ 가 처리된 상태에서는 $\mathrm{p} 38$ 의 저해제인 SB203580 처리시 HIF-1a 발현이 증가되었다(Fig. 3B). 이는 p38인산화 저해에 의해 세포생존을 위한 다른 신호전달 기전을 통하여 HIF-1a 발현을 증가시킬 것이라고 예상되며 그에 따른 연구는 더욱 수행되어야 할 것으로 생각된다.

봉독은 여러 가지 폴리펩타이드로 이루어져 있으며, 그 중 멜리틴과 아파민의 주요생리활성 물질로 염증성 질병에 이용 되어왔다[11]. 현재 보고에 따르면 봉독의 멜리틴 성분은 세포 자살을 유발하여 항암작용, 암세포 성장억제 등 여러 효과가 있으며[22,33]. 아파민 또한 여러 항암작용과 한의학에서 약 침용으로 사용하며 항염증 작용에 효과가 있다고 보고되고 있다[33]. 앞선 실험 결과, 봉독이 ERK1/2 단백질 인산화를 조절하여 HIF-1a 발현을 억제함을 확인하였으므로, 봉독의 주 요 생리활성 성분인 멜리틴과 아파민을 각각 처리하여 어떠한 성분에 의한 효과인지 확인하였다(Fig. 4). 실험 결과 HCT116 세포에서 $\mathrm{CoCl}_{2}$ 로 유도된 $\mathrm{HIF-1a}$ 발현이 아파민, 멜리틴에 의 해 모두 감소하는 경향을 보였으며 특히 아파민이 더욱 효과 적이었다(Fig. $4 \mathrm{~A}$ and $4 \mathrm{~B})$. $\mathrm{CoCl}_{2}$ 로 유도된 VEGF mRNA 수 준 또한 아파민에 의해 감소하였다(Fig. 4A). 그러나 멜리틴 처리에는 VEGF mRNA의 변화가 나타나지 않았다(Fig. 4B). 


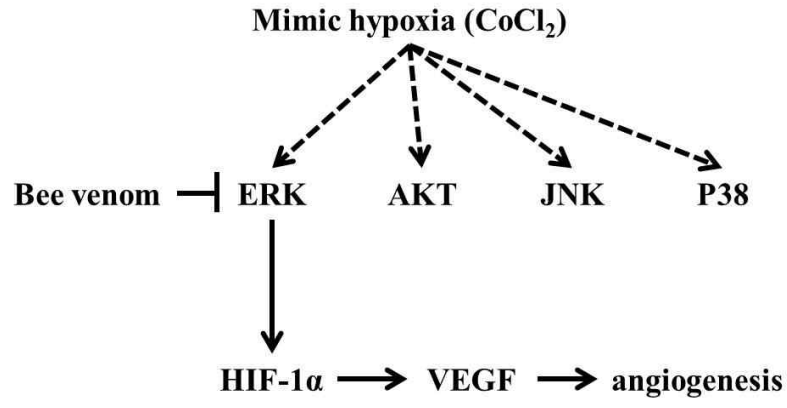

Fig. 5. Bee venom inhibits tumor angiogenesis. Bee venom decreased the HIF-1a protein synthesis in the $\mathrm{CoCl}_{2}-$ stimulated condition by inhibiting the ERK. Moreover, bee venom showed an anti-angiogenesis effect by decreasing the VEGF expression through inhibition of the HIF-1a protein. Therefore, this study demonstrated that bee venom is a potential inhibitor of the growth, invasion, and metastasis of tumors by inhibiting HIF-1a and VEGF protein expression.

그러므로 봉독의 신생혈관생성 효과는 아파민에 기인한 것이 라 생각된다.

결론적으로, 봉독은 ERK1/2 단백질 인산화를 억제함으로 써 HIF-1a 단백질 발현을 감소시켜 신생혈관생성 억제효과가 있는 것으로 나타냈으며(Fig. 5), 이러한 효과는 봉독의 주요 생리활성 성분인 아파민이 주요한 역할을 할 것이라 생각된 다. 본 연구를 통하여, HIF- $1 a$ 의 발현 억제를 표적으로 하여 봉독이 암세포 증식억제와 치료제로서 사용 가능성이 있음을 새롭게 확인하였다.

\section{감사의 글}

본 연구는 농촌진흥청 차세대바이오그린21사업(과제번호: PJ0081302011)에 의하여 수행되었으므로 감사를 드립니다.

\section{References}

1. Brahmachari, H. D. and S. Joseph. 1973. Cobalt compounds for the control of hypoxic stress. Aerosp Med 44, 636-638.

2. Bremnes, R. M., C. Camps, and R. Sirera. 2006. Angiogenesis in non-small cell lung cancer: the prognostic impact of neoangiogenesis and the cytokines VEGF and bFGF in tumours and blood. Lung Cancer 51, 143-158.

3. Cho, H. J., Y. J. Jeong, K. K. Park, Y. Y. Park, I. K. Chung, K. G. Lee, J. H. Yeo, S. M. Han, Y. S. Bae, and Y. C. Chang. 2010. Bee venom suppresses PMA-mediated MMP-9 gene activation via JNK/p38 and NF-kappaB-dependent mechanisms. J. Ethnopharmacol. 127, 662-668.

4. Chu, S. T., H. H. Cheng, C. J. Huang, H. C. Chang, C. C. Chi, H. H. Su, S. S. Hsu, J. L. Wang, I. S. Chen, S. I. Liu, Y. C. Lu, J. K. Huang, C. M. Ho, and C. R. Jan. 2007.
Phospholipase A2-independent $\mathrm{Ca}^{2+}$ entry and subsequent apoptosis induced by melittin in human MG63 osteosarcoma cells. Life Sci. 80, 364-369.

5. Cristofanilli, M., C. Charnsangavej, and G. N. Hortobagyi. 2002. Angiogenesis modulation in cancer research: novel clinical approaches. Nat. Rev. Drug Discov. 1, 415-426.

6. Dery, M. A., M. D. Michaud, and D. E. Richard. 2005. Hypoxia-inducible factor 1: regulation by hypoxic and non-hypoxic activators. Int. J. Biochem Cell Biol. 37, 535-540.

7. Fox, S. B., K. C. Gatter, and A. L. Harris. 1996. Tumour angiogenesis. J. Pathol. 179, 232-237.

8. Giles, F. J., W. T. Bellamy, Z. Estrov, S. M. O'Brien, S. Verstovsek, F. Ravandi, M. Beran, P. Bycott, Y. Pithavala, H. Steinfeldt, S. D. Reich, A. F. List, and K. W. Yee. 2006. The anti-angiogenesis agent, AG-013736, has minimal activity in elderly patients with poor prognosis acute myeloid leukemia (AML) or myelodysplastic syndrome (MDS). Leuk Res. 30, 801-811.

9. Gorlach, A., I. Diebold, V. B. Schini-Kerth, U. BerchnerPfannschmidt, U. Roth, R. P. Brandes, T. Kietzmann, and R. Busse. 2001. Thrombin activates the hypoxia-inducible factor-1 signaling pathway in vascular smooth muscle cells: Role of the p22 (phox)-containing NADPH oxidase. Circ. Res. 89, 47-54.

10. Hanahan, D. and J. Folkman. 1996. Patterns and emerging mechanisms of the angiogenic switch during tumorigenesis. Cell 86, 353-364.

11. Hao, J., M. G. Liu, Y. Q. Yu, F. L. Cao, Z. Li, Z. M. Lu, and J. Chen. 2008. Roles of peripheral mitogen-activated protein kinases in melittin-induced nociception and hyperalgesia. Neuroscience 152, 1067-1075.

12. Hon, W. C., M. I. Wilson, K. Harlos, T. D. Claridge, C. J. Schofield, C. W. Pugh, P. H. Maxwell, P. J. Ratcliffe, D. I. Stuart, and E. Y. Jones. 2002. Structural basis for the recognition of hydroxyproline in HIF-1 alpha by pVHL. Nature 417, 975-978.

13. Huh, J. E., Y. H. Baek, M. H. Lee, D. Y. Choi, D. S. Park, and J. D. Lee. 2010. Bee venom inhibits tumor angiogenesis and metastasis by inhibiting tyrosine phosphorylation of VEGFR-2 in LLC-tumor-bearing mice. Cancer Lett. 292, 98-110.

14. Ivan, M., K. Kondo, H. Yang, W. Kim, J. Valiando, M. Ohh, A. Salic, J. M. Asara, W. S. Lane, and W. G. Kaelin, Jr. 2001. HIFalpha targeted for VHL-mediated destruction by proline hydroxylation: implications for O2 sensing. Science 292, 464-468.

15. Jang, M. H., M. C. Shin, S. Lim, S. M. Han, H. J. Park, I. Shin, J. S. Lee, K. A. Kim, E. H. Kim, and C. J. Kim. 2003. Bee venom induces apoptosis and inhibits expression of cyclooxygenase-2 mRNA in human lung cancer cell line NCI-H1299. J. Pharmacol Sci. 91, 95-104.

16. Jeon, S., N. H. Kim, B. S. Koo, H. J. Lee, and A. Y. Lee. 2007. Bee venom stimulates human melanocyte proliferation, melanogenesis, dendricity and migration. Exp. Mol. Med 39, 603-613.

17. Jiang, B. H., G. Jiang, J. Z. Zheng, Z. Lu, T. Hunter, and 
P. K. Vogt. 2001. Phosphatidylinositol 3-kinase signaling controls levels of hypoxia-inducible factor 1. Cell Growth Differ. 12, 363-369.

18. Leung, D. W., G. Cachianes, W. J. Kuang, D. V. Goeddel, and N. Ferrara. 1989. Vascular endothelial growth factor is a secreted angiogenic mitogen. Science 246, 1306-1309.

19. Lin, C. W., W. C. Hou, S. C. Shen, S. H. Juan, C. H. Ko, L. M. Wang, and Y. C. Chen. 2008. Quercetin inhibition of tumor invasion via suppressing PKC delta/ERK/AP-1dependent matrix metalloproteinase- 9 activation in breast carcinoma cells. Carcinogenesis 29, 1807-1815.

20. Masson, N., C. Willam, P. H. Maxwell, C. W. Pugh, and P. J. Ratcliffe. 2001. Independent function of two destruction domains in hypoxia-inducible factor-alpha chains activated by prolyl hydroxylation. EMBO. J. 20, 5197-5206.

21. Maxwell, P. and K. Salnikow. 2004. HIF-1: an oxygen and metal responsive transcription factor. Cancer Biol. Ther. 3, 29-35.

22. Moon, D. O., S. Y. Park, Y. H. Choi, N. D. Kim, C. Lee, and G. Y. Kim. 2008. Melittin induces $\mathrm{Bcl}-2$ and caspase-3-dependent apoptosis through downregulation of Akt phosphorylation in human leukemic U937 cells. Toxicon. 51, 112-120.

23. Moon, D. O., S. Y. Park, M. S. Heo, K. C. Kim, C. Park, W. S. Ko, Y. H. Choi, and G. Y. Kim. 2006. Key regulators in bee venom-induced apoptosis are Bcl-2 and caspase-3 in human leukemic U937 cells through downregulation of ERK and Akt. Int. Immunopharmacol. 6, 1796-1807.

24. Moyrand, F., T. Fontaine, and G. Janbon. 2007. Systematic capsule gene disruption reveals the central role of galactose metabolism on Cryptococcus neoformans virulence. $\mathrm{Mol}$. Microbiol. 64, 771-781.

25. Park, M. H., M. S. Choi, D. H. Kwak, K. W. Oh, D. Y. Yoon, S. B. Han, H. S. Song, M. J. Song, and J. T. Hong. 2010. Anti-cancer effect of bee venom in prostate cancer cells through activation of caspase pathway via inactivation of NF-kappaB. Prostate [Epub ahead of print].

26. Patra, S. K. 2008. Dissecting lipid raft facilitated cell signaling pathways in cancer. Biochim Biophys Acta. 1785, 182-206.

27. Raspollini, M. R., F. Castiglione, F. Garbini, A. Villanucci, G. Amunni, G. Baroni, V. Boddi, and G. L. Taddei. 2005. Correlation of epidermal growth factor receptor expression with tumor microdensity vessels and with vascular endothelial growth factor expression in ovarian carcinoma. Int. J. Surg Pathol. 13, 135-142.

28. Richard, D. E., E. Berra, and J. Pouyssegur. 2000. Nonhypoxic pathway mediates the induction of hypoxia-inducible factor 1alpha in vascular smooth muscle cells. J. Biol. Chem 275, 26765-26771.
29. Salnikow, K., W. G. An, G. Melillo, M. V. Blagosklonny, and M. Costa. 1999. Nickel-induced transformation shifts the balance between HIF-1 and p53 transcription factors. Carcinogenesis 20, 1819-1823.

30. Salnikow, K., M. V. Blagosklonny, H. Ryan, R. Johnson, and M. Costa. 2000. Carcinogenic nickel induces genes involved with hypoxic stress. Cancer Res. 60, 38-41.

31. Shi, Y. H., Y. X. Wang, L. Bingle, L. H. Gong, W. J. Heng, Y. Li, and W. G. Fang. 2005. In vitro study of HIF-1 activation and VEGF release by bFGF in the T47D breast cancer cell line under normoxic conditions: involvement of PI-3K/Akt and MEK1/ERK pathways. J. Pathol. 205, 530-536.

32. Son, D. J., S. J. Ha, H. S. Song, Y. Lim, Y. P. Yun, J. W. Lee, D. C. Moon, Y. H. Park, B. S. Park, M. J. Song, and J. T. Hong. 2006. Melittin inhibits vascular smooth muscle cell proliferation through induction of apoptosis via suppression of nuclear factor-kappaB and Akt activation and enhancement of apoptotic protein expression. $J$. Pharmacol. Exp. Ther. 317, 627-634.

33. Son, D. J., J. W. Lee, Y. H. Lee, H. S. Song, C. K. Lee, and J. T. Hong. 2007. Therapeutic application of anti-arthritis, pain-releasing, and anti-cancer effects of bee venom and its constituent compounds. Pharmacol Ther. 115, 246-270.

34. Song, C. C., X. Lu, B. B. Cheng, J. Du, B. Li, and C. Q. Ling. 2007. Effects of melittin on growth and angiogenesis of human hepatocellular carcinoma BEL-7402 cell xenografts in nude mice. Ai Zheng. 26, 1315-1322.

35. Wang, C., T. Chen, N. Zhang, M. Yang, B. Li, X. Lu, X. Cao, and C. Ling. 2009. Melittin, a major component of bee venom, sensitizes human hepatocellular carcinoma cells to tumor necrosis factor-related apoptosis-inducing ligand (TRAIL)-induced apoptosis by activating CaMKII-TAK1$\mathrm{JNK} / \mathrm{p} 38$ and inhibiting IkappaBalpha kinase-NFkappaB. J. Biol. Chem 284, 3804-3813.

36. Wang, G. L. and G. L. Semenza. 1993. General involvement of hypoxia-inducible factor 1 in transcriptional response to hypoxia. Proc. Natl. Acad Sci USA 90, 4304-4308.

37. Wang, G. L. and G. L. Semenza. 1995. Purification and characterization of hypoxia-inducible factor 1. J. Biol. Chem 270, 1230-1237.

38. Zhong, H., K. Chiles, D. Feldser, E. Laughner, C. Hanrahan, M. M. Georgescu, J. W. Simons, and G. L. Semenza. 2000. Modulation of hypoxia-inducible factor 1alpha expression by the epidermal growth factor/phosphatidylinositol 3-kinase/PTEN/AKT/FRAP pathway in human prostate cancer cells: implications for tumor angiogenesis and therapeutics. Cancer Res. 60, 1541-1545. 


\section{초록 : 봉독의 HIF-1a 발현감소를 통한 혈관신생 억제효과}

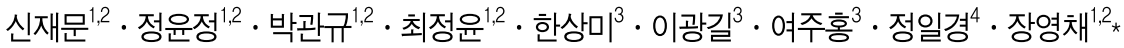

( ${ }^{1}$ 대구가톨릭대학교 의용생체공학연구소, ${ }^{2}$ 대구가톨릭대학교 의과대학 의학과, ${ }^{3}$ 농촌진흥청 국립농업과학 원, ${ }^{4}$ 대구가톨릭대학교 자연대학 생명공학과)

봉독은 동양의학에서 관절염, 류마티즘 및 각종 암을 포함하여 다양한 질병을 치료하기 위하여 이용되었다. 최근 봉독의 신생혈관 억제효과에 대한 연구가 보고되었으나 정확한 분자메커니즘에 대해서는 보고가 미흡하다. 따라서, 본 연구는 봉독이 인간결장암세포인 HCT116세포에서 신생혈관생성과 종양진행에 중요한 역할을 하는 HIF-1a와 VEGF 발현 억제효과를 조사하였다. 그 결과 봉독은 $\mathrm{CoCl}_{2}$ 로 유도한 저산소 상태에서 VEGF와, HIF-1a 의 발현을 감소시키며 HIF-1a의 promoter 영역인 HRE 활성을 억제하였다. 이러한 봉독의 HIF-1a 발현억제효과 는 ERK1/2의 인산화 조절을 통한 것이며, 봉독은 $\mathrm{p} 38, \mathrm{JNK}, \mathrm{AKT}$ 의 인산화에는 영향을 끼치지 않았다. 또한 봉독 의 효과를 나타내는 단일물질 탐색을 위해 봉독의 생리활성 물질로 알려진 아파민과 멜리틴을 조사한 결과, HIF-1a와 VEGF 억제효과는 아파민에 기인하는 것이라고 예상 할 수 있었다. 이와 같은 결과를 통하여 본 연구에 서는 봉독의 혈관신생 억제에 대한 새로운 신호전달기전 및 인간 결장암세포 전이 억제제로서의 잠재성을 확인 하였다. 